\title{
Increasing the Rural Economy of Village Owned Enterprises BUMDes Antajaya Bogor
}

\author{
Sri Widyastuti*, Sri Ambarwati \\ Faculty of Economic and Business \\ Universitas Pancasila \\ Jakarta, Indonesia \\ *widyastuti.sri@univpancasila.ac.id, sriambarwati@univpancasila.ac.id
}

\begin{abstract}
This article aims to map the potential of the Antajaya region in planning with the establishment of BUMDes in the region and how to strengthen its role in the rural economy. The research method used is qualitative, this study shows that the village of Antajaya in the future will become a rural economic strength. Open opportunities that can be developed into agropolitan areas, namely the economic, agribusiness, agrotourism and agro-industrial areas, including coffee education tourism. In addition, it also enhances the role of BUMDes not only as a mediator of government funds, but also as a facilitator to increase economic activities well, so that village income will also increase. Antajaya Village already has a BUMDes Mitra Sejahtera Mandiri that can improve the Rural Economy with potential, so that it can be developed into educational tourism, but it still depends a lot on human resources issues, it is necessary to provide assistance for people who change the mind-set of rural communities by introducing the concept of Social Enterprise.
\end{abstract}

Keywords: BUMDes, rural economy, social enterprises

\section{INTRODUCTION}

Village-owned enterprises/ BUMDes economic institutions are pillars of rural economic activity, functioning as social and commercial institutions. According to Law No. 6 of 2014 [1] of the BUMDes: The village can establish village-owned enterprises, BUMDes can be managed with a spirit of brotherhood and cooperation, BUMDes can run the business in the field of economic and public service by the provisions of the legislation. One of the efforts to empower from the government of village autonomy, which is that the village can manage resources independently and adaptively one of them is through BUMDes [2]. According to Nyoman and Romi [3], BUMDes has played a role as the implementation of the creative economy in order to empower villagers, because BUMDes has strengthened village income, so that villages are able to independently finance village activities so as to realize improved living standards while also preserving the customs and culture of the community. BUMDes can be a means to realize the economic independence of the village in order to improve the welfare of the village community, because its presence can improve the economy and open employment in the village. This can be realized if all village officials are able to understand and apply the Village Law and the Ministry of Health Regulation on BUMDes properly and correctly in their respective villages. Establishment of BUMDes aims as a locomotive of village-level local economic development. The local economic development of the village is based on the needs, potential, capacity of the village, and capital participation from the village government in the form of financing and village wealth. This aims to improve the economic level of rural communities. The basis for the establishment of BUMDes is based on government and village community initiatives based on cooperative, participatory and emancipatory principles.

Kiky [4] stated to increase the participation of villagers through village forums, because by increasing the role of village communities it was a way to promote the sense of ownership of villagers to village-owned companies. Village forums can be a medium for sharing thoughts, ideas and information. But in reality there are still backward BUMDes and need the help of many parties. This research identifies problems that hamper the development of BUMDes and provides solutions for immediate development. This paper aims to explain how to strengthen the role of village-owned companies for their role in improving the economy of village communities. BUMDes. The main problem hampering the development of BUMDes from the internal side is the lack of business management and institutional management capabilities owned by managers, while from the external side is product marketing competition. While internal solutions that can be used to solve this problem are partnerships with various parties such as companies, or other village-owned BUMDes and companies that have the same spirit [4]

According to Jefri [5] the problems faced by village-owned companies include lack of capital, lack of socialization by the Regional Government, and lack of honour given to BUMDes employees. These constraints occur due to lack of preparation from the local government and village government to organize village-owned companies. In addition to natural obstacles that can affect BUMDes financial performance, other factors are capital, responsibility, education, and type of business. Wiagustini [6] states that internal strategic factors and external strategic factors affect the strategic position of the development of rural credit institutions, namely the strong attraction and medium competitiveness. The appropriate partnership strategic model applied is an integrated and intensive partnership strategy. Sudaryono [7] states that the 
implementation of policies on BUMDes management is in the management of human resources, and the participation of the private and government sectors and assistance and how much it benefits the welfare of rural communities.

As for the problems in the implementation of BUMDes, including covering the lack of community participation in managing BUMDes, the village government does not optimally empower the community to develop BUMDes and BUMDes does not work [8]. There are various obstacles faced by villagers in carrying out development including: limited ability to process and utilize available natural resources, remoteness and limited physical infrastructure, weak institutional capacity of existing service and trade business opportunities. Limited access to sources of economic progress includes the following: access to capital, access to production technology, access to business management, knowledge and skills in human resources, access to market information and efforts to sustain production [9].

Village-owned enterprises are business entities of all or most of their capital owned by the village through direct participation of village assets separated from the management of assets, services, and other businesses for the welfare of the villagers [10]. Kurniawan [11] stated that regional development strategies in Indonesia starting from the economic sector starting from the grassroots community so that the central government expects that the village government (lower government) has a business entity as a source of income that can support the economic growth of the community and the business entity is called.

\section{METHODS}

The research method used is a qualitative approach to data collection techniques, namely interviews, observation, and document review. The results of interviews with Village Officials, Village Head Mr. Tatang Rahmat, S.E, Village Secretary Asep Darda and Chairperson of the Village Consultative Body Mr. Kusnadi as well as a review of several craft locations about a number of potential village areas and the obstacles they face.

\section{RESULTS AND DISCUSSION}

Antajaya Village is a remote village and is one of ten villages in Tanjungsari Subdistrict namely; Buanajaya, Cibadak, Pasir Tanjung, Selawangi, Sirnarasa, Sirnasari, Sukarasa, Tanjungrasa and Tanjungsari, The geographical location of Antajaya Village is located between 644 - 708.3 North Latitude and 107.21 - 108.21 East Longitude with an area of $797.22294 \mathrm{Ha}$ and consists of 4 hamlets with 5 neighbourhood units (RW). The north is bordered by Cariu District, the east is bordered by Purwakarta Regency, the south is bordered by Buanajaya Village and the west is bordered by Tanjung Rasa Village. While the distance of Antajaya Village to Tanjung Sari District is $7 \mathrm{Km}$, to Bogor Regency is $62 \mathrm{Km}$, to the City of West Java Province is $96 \mathrm{Km}$ and to Jakarta is $81 \mathrm{Km}$. Tanjungsari Subdistrict becomes the boundary line of Bogor Regency and Cianjur Regency, along the highway lanes the area of rice fields and plantations owned by residents is surrounded by mountains and hills such as Mount Karang,
Kandaga, Kembar, Sangga Buana and Sangyang with a height of 300 - 500 meters above sea level, with an average rainfall of 100-200 MM / HM and an average air temperature of 27-30 degrees Celsius. The five mountains are forest buffer zones of Tanjungsari District. As a water catchment area, these forests are the eastern part of the Perhutani working area, under the auspices of the Bogor Forest Management Unit (KPH) directly adjacent to the Purwakarta KPH and Cianjur KPH. Furthermore, hydrological aspects are very much needed in the control and regulation of village water systems. There are Ciliwung, Citarum, Cisadane and Cidurian Watersheds. Antajaya village has many tributaries namely; Muara Tiga River, Cibeet River, Cikembar River, Cimanggu River, Cigoha River, Cibaregbeg River, Cibogo River and Ciomas River. In addition, Antajaya Village has several sources of clean water sources to meet the needs of residents, namely the Muara Tiga spring, the Jeruk Nipis spring, Cikembar spring, Ciburial spring and Ciomas River. The four watersheds are the source of irrigation of rice fields and gardens owned by residents in Tanjungsari Sub districts, the majority of whose inhabitants are farmers. While the area of Antajaya Village is $797,229 \mathrm{Ha}$ of the land area used as a plot of land for settlement 98,30 Ha, technical rice field area 132,80 Ha, plantation area $121,20 \mathrm{Ha}$, land area in the form of ponds 150 $\mathrm{Ha}$, area of rain-fed rice fields $139,20 \mathrm{Ha}$, the area of community forest is $450 \mathrm{Ha}$ and the area of land is $750 \mathrm{Ha}$ of state forest. Furthermore, the population based on the results of the 2018 census of 5,992 people consisted of 3,006 men and 2,986 women, with a total of 1,879 heads of households. Education level, not graduated from elementary school 316 people, graduated from elementary school 1,055 people, graduated from junior high school 2,787 people, graduated from senior high school 1,423 people, graduated 13 from D1, 18 from D2 from 18, graduated from D3 by 27, graduated from $S 1$ by 18,2 from S2. While the work of Antajaya Village residents are 414 people, 495 people, 355 people, entrepreneurs, 434 people, agriculture and 284 people. Government apparatus and institutional members, village head, village secretary, head of affairs $=6$ people, head of subvillage $=4$ people, Village Consultative Body $/ \mathrm{BPD}=9$ people, $\mathrm{RW}$ chief $=6$ people, $\mathrm{RT}$ head $=16$ people, Community Protection Agency $=10$ people.

\section{A. Potential and Problems of Antajaya Village}

Antajaya Village has the following potential:

1) Natural resources: Can support village development programs in the form of rock resources, wood in the form of albasia wood, bamboo, seasonal fruits such as (durian, rambutan, mangosteen, duku, petai, robusta coffee, coffee arabica), agriculture, tourist attractions in the form (Curuk Tujuh waterfall, educational tour to coffee plantations, and mountains) and sleeping areas are still quite extensive.

2) Human resources (HR): the community has a high enthusiasm to build their village including still willing to give away their land in the public interest, to build roads, mosques, posyandu and others, the spirit of mutual cooperation is still high, the concern for contributions / donations is still high, available technical staff (carpenters, tailors, bricklayers), 
BUMDes management missed a number of things in determining the business to be run. The selection of BUMDes businesses must be adjusted to the capabilities of the human resources in Antajaya village. It will be better and easier to run if BUMDes has the expertise in the chosen business. BUMDes Mitra Sejahtera Mandiri is engaged in collecting Robusta Coffee harvest from the community, but this business is not going well because many people sell it directly to middlemen. Here it seems that BUMDes Mitra Sejahtera Mandiri is present only a means for compliance with regulations. BUMDes Mitra Sejahtera Mandiri is still in the process of finding an ideal form as a business, where it is not yet understood the existence of BUMDes that is comprehensively managed which has implications for two main aspects namely BUMDes institutions and financial management. In addition, there is still a lack of adequate human resources in the management of BUMDes, BUMDes has not been able to carry out its functions to the maximum, only one of the fields that is still running, and the lack of public awareness in developing other business fields. So that in this modernization era a strategy is needed in realizing village independence and alleviating problems or obstacles in implementing BUMDes through an innovation to improve the welfare and economy of rural communities by developing BUMDes innovations. But in the implementation there are some problems that arise. Problems in the implementation of BUMDes, including: lack of community participation in the management of BUMDes; village government does not optimally empower the community to develop BUMDes; and not running BUMDes. BUMDes should be present as a collective need of the community to develop and improve the village economy. This is due to the limited insight and access to information which is the reason why the management of BUMDes Mitra Sejahtera Mandiri has not been able to become a mainstay in producing Village Original Revenues (PADes).

\section{Proposed Solution}

One of the biggest obstacles for villages in establishing BUMDes is their inability to understand the potential in their area to be used as business land. So far, the potential is always interpreted as the availability of natural resources or natural beauty in the village. Efforts are needed to change the mindset so that potential is not always interpreted narrowly. The other side are there are still many villages in all corners of the earth of this Pancasila which lack creativity and innovation. HR from the Antajaya village community is graduating Postgraduate as many as 78 qualified people can be involved as a driving force in the management of BUMDes. However, not all HR can act as quality BUMDes retainers to help BUMDes, so that it can help realize the goal of generating Village Original Revenue (PADes).

The steps taken to change the mind-set of rural communities by introducing the concept of Social Enterprise. This concept is in line with the BUMDes philosophy which is to bring benefits and benefits to the community. Therefore it becomes important that there is collaboration from various elements or parties in efforts to build and develop BUMDes. One of the supporters of the creation of this collaboration is to strengthen cooperation or cooperative principles. The concept of Social Enterprise is a strategy to solve social problems in 
society through the establishment of business units. It should be noted that, the BUMDes management concept cannot directly replicate other business entities, it is necessary to adapt to various local wisdoms in the village. The benefits must be in line with the positive impact received by the community and provide benefits in the village. Enlightenment to change mind-set by introducing the concept of landscape mapping as a tool to recognize the potential and business opportunities in the village of Antajaya. After changing the participant's mind-set, it is important to provide the right method for follow-up. The concept of landscape mapping can be a 'knife of analysis' that provides a comprehensive picture of the business potential. After conducting landscape mapping, the next strategy is to use SWOT analysis to deepen the results and landscape mapping. SWOT analysis is useful for knowing external and internal analysis and various range points that have been done before [12].

The strategies that can be done to reach the independent village are by implementing innovations in every joint venture BUMDes. In addition, optimization is carried out in each village's assets and village potential to improve community welfare. There are 3 (three) sectors that are the focus of efforts to realize the independence of a village, namely: (a) economic potential; (b) social potential; and (c) Human Resources (HR) potential. Economic potential as the most important part in efforts to improve the standard of living of the people requires business innovation in the management of BUMDes. One of them can apply information technology in business development efforts carried out by BUMDes. Social potential refers to the availability of workers coming from rural communities who have skills and competencies in several sectors, so that empowerment and community involvement can be done by BUMDes to create new jobs. HR potential as a supporting factor in managing BUMDes towards a more professional direction, so that BUMDes can become a productive, creative, innovative, adaptive and accountable business institution. The advantage of Antajaya village is that it has a large enough coffee plantation potential of 32 hectares owned by the government, private sector and smallholder plantations. In the village of Antajaya working as coffee farmers as many as 500 people in the vast coffee plantations Robusta and Arabica types. This coffee commodity has the potential to be a buffer for people's economic life, especially farmers. The views of rice fields and mountains and the potential of water resources are also an attraction in addition to the andesite rock mining in the Kandaga Mountains. The weakness that has been successfully portrayed is that the community has a high enthusiasm to build their village but their fighting power is still weak to develop business creativity, the village officials have not fully understood the benefits of the BUMDes. This weakness is also an obstacle when many people from the city take over ownership of land and mine andesite stone, so it is feared that it will have an impact on the shift in implementing Social Enterprise. The need to promote the existence of BUMDes, take collaborative actions with third parties, such as companies, or other villageowned enterprises around the village of Antajaya and companies that have the same spirit. Another important issue that must not be ignored is the way to increase the participation of villagers. Improving village communities through village forums can be a way to increase the sense of ownership of villagers about the existence of BUMSes. Village forums can be a medium for sharing thoughts, ideas and information.

Recommendations that can be given based on the results of research are that all villages are expected to provide great opportunities for business operators in the village to interact with the village government in forming BUMDesa. In addition, BUMDesa must be able to accommodate entrepreneurs in the village to develop the potential of their community and not create social jealousy in any form. When viewed in terms of legality, it can be suggested that the establishment of BUMDesa is legally covered by Village Regulations so that rural business people can freely create creations in developing their business or types of products but not out of the regulations.

Antajaya village, Tanjungsari sub-district, Bogor regency can be developed as an advanced and victorious agropolitan village. The agropolitan area is an area of agribusiness, agrotourism and agro-industrial economies consisting of centres of production, processing, marketing, trade, services, and other interrelated activities that are carried out in an integrated manner. The main economic drivers in the agropolitan area can be in the form of production and trade activities, horticulture, tourism-based agricultural and agroindustry tourism areas, including coffee education tours. Thus the hope of making the Antajaya village prosperous will soon be realized.

\section{REFERENCES}

[1] Law No. 6 of 2014 About the village government even has a Special chapter is chapter 10 of Article 87, 2014

[2] F.P.L. Rika, "Mengembangkan kualitas usaha milik desa (Q-Bumdes) untuk melestarikan ketahanan ekonomi masyarakat dan kesejahteraan adaptif: Perancangan sistem kewirausahaan desa dengan menggunakan model tetrapreneur," Jurnal Studi Pemuda, vol.7, no. 2, pp. 122-132, 2018.

[3] S. Nyoman and S. Romi, "The role of the village business agency as creative economic implementation in order of community empowerment of villages of Cagak Road Subang District West Java Province, International Journal of Information Technology and Business Management", vol. 58, no. 1, pp. 8-21, 2017.

[4] S. Kiky, "Empowering the role of village owned enterprises (bumdes) for rural development: Case of Indonesia," Journal of Accounting, Management and Economics, vol. 20, no. 1, pp. 5-10, 2018.

[5] S. Jefri, "Perlindungan Hukum Pengguna Jasa Layanan Go-Ride Menurut Undang-Undang Nomor 8 Tahun 1999 Tentang Perlindungan Konsumen (Studi kasus PT. Aplikasi Karya Anak Bangsa cabang Bukittinggi)," 2019, unpublished.

[6] N.L.P. Wiagustini, "Partnership strategy of Village-Owned Enterprises (Village Credit Institutions and Village Markets) In Denpasar City, Indonesia," International Journal of Economics, Commerce and Management, United Kingdom, Licensed Under Creative Common, vol. 3, Issue 4, pp. 1-20, 2015.

[7] Sudaryono, Manajemen Pemasaran, Yogyakarta: Penerbit Andi, 2016

[8] H. Purnamasari, E. Yulyana, and R. Ramdani, "Efektivitas Pengelolaan Badan Usaha Milik Desa (BUMDesa) berbasis ekonomi kerakyatan di desa Warungbambu, Kecamatan Karawang Timur Kabupaten Karawang," Jurnal Politikom Indonesiana, vol. 1, no. 2, pp. 31-42, 2016.

[9] A. Suriadi, K. Mahalli, N. Achmad, and I. Muda, "The applicative model of the Village-Owned Enterprises (BUMDes) development In 
North Sumatera," Global Journal of Arts, Humanities and Social Sciences, vol. 3, no. 12, pp.48-62, 2015.

[10] H. Kamaroesid, Tata Cara Pendirian Dan Pengelolaan Badan Usaha Milik Desa, Jakarta: Mitra Wacana Media, 2016
[11] I.F. Kurniawan, "Development of village owned enterprises (bumdes) as a solution to achieve mandiri village," International Journal Of Business And Economic A_Airs (IJBEA), vol. 3, no. 5, pp. 185-194, 2018.

[12] Bumdes.id, Pusat Informasi dan Pelatihan Bumdes, 2018. 